\title{
The Influence of American Consumption Habits on the Theft of American Credit Cards
}

\author{
Mengling Wei \\ College of Art \& Sciences, University of Miami, FL, The United States \\ mxw759@miami.edu
}

\begin{abstract}
Credit card payment has been flourishing in marketing transaction in the United States for decades, while variety of consumer behavior and digital development bring about new impacts on financial theft. The gender, the credit card knowledge, and country-based institutions would be some significant consumptions habits aspects that related to the credit card theft. Furthermore, consumers consider online shopping with credit card payment as a riskier but more effective purchase approach compared to the traditional shopping. Based on the past results, the easy conducts the survey study by five-point Likert response scale method with face-to-face questionnaire on students, exploring their credit cards consumption habits deeper, including related knowledge, lifestyle outcomes of usage and usage practices. The findings reveal that firstly the relationship between the card ownership time and consumption increase is inverse. Consumer owning credit cards over five years would be more likely to gain short-term financial support via credit card. Additionally, students' attitudes towards credit cards are turning negative over time, leading to the decline of the number and the usage of the credit card. Finally, although the consumers believe the online shopping is riskier, they still seek for the convenience or time saving from this purchase pattern, putting more risk on the theft of credit cards.
\end{abstract}

\section{Keywords: Online Shopping, Credit Card, Consumption Habits, Transaction}

\section{INTRODUCTION}

According to Norvilitis (2014), client deeds involve all client undertakings linked to the buying, utilization, and discarding of services and products, incorporating the customers' behavioral, mental, and emotional responses that influence or follow these undertakings. Understanding how and why individuals utilize services and products assists marketers comprehend ways in which they can enhance existing goods, the types of required goods in the marketplace, and the manner in which they can influence clients to purchase their products. Attitudes determine customer's consumption and purchase intents, business organizations are extremely interested in understanding about attitudes of customers towards their goods. According to Becker et al. (2010), the main reason why business organizations are interested in understanding this concept is because the idea will heavily impact the manner in which they create promotional and marketing advertisements.

Since 1960s, it has become possible to use digital data networks. Credit card payment is one of the earliest daily digital media practices (Gießmann, 2018b) ${ }^{[5]}$. The United States has one of the largest numbers of credit card holders in the world, and the coverage of credit cards is very wide. Due to the long history of credit card, the United States has a very complete credit card consumption system. Therefore, American consumers are used to spending in advance and enjoy all kinds of discounts at the same time. The results of previous studies shows that credit card holders' consumption habits are influenced by factors such as ages, social demographic attributes, knowledge about credit cards and perceived lifestyles.

Since 20th century, fraud became more and more mature in the field of transaction business, most notably in the telecommunications and credit card industries. Fraud is dishonestly trying to convince innocent parties that legitimate transactions are taking place (Becker et al., $2010)^{[1]}$. The theft of credit card or card fraud is always a big problem in the United States' credit system, A class of "elite" hackers can now usually attack websites, extract credit card account information, and then cover up their tracks by destroying digital evidence along the way (Boni, $2002)^{[2]}$. Although the theft rate of credit cards in the United States is very high, as long as the credit card holders report the issue to the bank, the bank will return 
the stolen money to the credit card holder as soon as possible.

This paper will analyze American credit card user's consumption habits from different perspectives first, then discover how these consumption habits influence the theft of credit card in American credit market. To effectively attain this objective, this investigation will be based on Information Integration philosophy which analyzes the manner in which attitudes are created and altered through the addition of new facts with prevailing thoughts or cognitions.

\section{LITERATURE REVIEW}

For the purpose of understanding the influence of American consumption habits on the theft of American credit cards, we need to learn about the American credit card holders first. To investigate the ownership and practice usage of credit card, Wickramasinghe \& Gurugamage conducted a research in Sri Lanka. The study used the survey research method, and tests the hypothetical relationship through path analysis to determine and evaluate the impact of credit card users' demographic and socio-economic characteristics, credit card knowledge and perceived lifestyle results on credit card use practice (Wickramasinghe \& Gurugamage, $2011 b)^{[4]}$. The author concluded that gender is significantly correlated with the perceived lifestyle of credit card use, users in high-income groups have a higher understanding of credit risk and People's financial literacy has a significant impact on debt (Wickramasinghe \& Gurugamage, 2011b) ${ }^{[4]}$.

Student is a very important group of credit card holders. Norvilitis' study investigated the changes of College Students' debt and credit card holdings on an American university campus, as well as their attitudes towards debt and credit card. The results show that after the promulgation of the credit card law in 2009, the amount of credit card holdings and credit card debts have decreased. The relationship between students and credit cards seems to be changing, but many people still have difficulty managing credit cards (Norvilitis, 2014b) ${ }^{[12]}$.

Different countries will implement different credit strategies according to their national conditions. The strategies used by Russian and American banks to evaluate the credit of potential credit card holders are compared. According to knight's risk and uncertainty theory, Guseva \& Rona-Tas believes that the inherent uncertainty in any credit transaction can be reduced to measurable risk only when institutions create stability over time, properly classify events and allow verification and accumulation of information (Guseva \& Rona-Tas, $2001)^{[6]}$. In the United States, the gradual evolution of the system supporting rational computing allows uncertainty to be transformed into risk. However, in Russia, such institutions do not exist, and there is a great degree of uncertainty in consumer credit Using data from the original field survey in Moscow, this study shows that participants rely on trust when they face uncertainty and cannot calculate risk. Russian banks take advantage of and expand their existing social relations or, in some cases, establish new ones. They also use the cardholder's own network unrelated to the bank to increase their responsibility through anchoring. However, these strategies make the market embedded, limited in scale and uninsured( Guseva \& Rona-Tas, 2001) ${ }^{[6]}$.

When we talk about theft of credit card, online credit card theft is a big topic. DelVecchio conducted an exploratory study to examine how consumers assess the risks associated with using credit cards online. The results of this study support the view that Consumers believe that online shopping is more risky than traditional shopping. Consumers may be worried about losing many forms of resources (such as finance and time). Consumers' perception of convenience (or time) loss is different from other dimensions. If they suffered credit card theft online, consumers think the most likely result is the loss of convenience or time. If online shoppers value convenience, it may be a resource that retailers want to protect (DelVecchio et al., 2002) ${ }^{[3]}$. Consumers might be intimidated by the time-consuming activities they must undertake to avoid or correct online credit card theft.

\section{METHOD}

F Wickramasinghe and Gurugamage's study measurement method is based on the insight obtained from the previously reviewed literature (mainly based on the West) and the insight obtained by the two authors during their preliminary survey in Sri Lanka. All structures were measured using the five-point Likert response scale, ranging from 1 (strongly disagree) to 5 (strongly agree). 10 credit card users were randomly selected and matched with the survey participants. Before collecting data, the participants were informed of the purpose of the study, and their answers were anonymous. The research tool was structured questionnaire. The questionnaire was administered through face-to-face personal interviews in September and November 2007. All survey interviews were conducted by the second author of this study, and the survey time was about 15 minutes(Wickramasinghe \& Gurugamage, 2011a) ${ }^{[14]}$. The survey consists three parts, knowledge about credit cards, perceived lifestyle outcomes of credit card usage and credit card usage practices.

1121 students participated in Norvilitis' study on student credit card attitude, 883 students provided both income and credit card debt information. Data collection was conducted five times, and each data collection cycle is one semester. Although the data were collected in five independent surveys, the whole process was the same. Participants were contacted in the classes of various departments and were asked to participate in the research 
on College Students' attitudes and beliefs on some personal topics, including credit card and credit card debt. With written consent, participants were given questionnaires containing the scales described below, as well as other specific scales for each original study, which will be completed after class and returned in the next course. Students report the number of major credit cards held (such as visa and MasterCard) and their current credit card debt and annual income. The students also reported the possibility of paying off their credit cards every month. The project is rated on a scale of 1 to 4 . The higher the score, the more likely it is to pay the balance in full each month. Students completed a measurement of students' attitudes towards debt (Norvilitis, 2014a) ${ }^{[12]}$. The scale consists of 14 items and adopts a 5-point Likert scale, from "strongly agree" to "strongly disagree". It aims to assess the debt tolerance of college students. A higher score indicates a higher tolerance for debt. The delayed gratification scale (Norvilitis, 2014a) ${ }^{[12]}$ is a 12 item index, which is divided into yes, no or uncertain. It includes delayed purchases and other satisfaction. The higher the score, the greater the delay of self-reported satisfaction. The financial health scale (Norvilitis, $2014 a)^{[12]}$ assessed students' perception of financial health. This 8-item measurement was completed on a 5point scale, from "strongly agree" to "strongly disagree". The higher the score, the better the financial situation. The financial health scale (Norvilitis, 2014a) ${ }^{[12]}$ assessed students' perception of financial health. This 8-item measurement was completed on a 5-point scale, from "strongly agree" to "strongly disagree". The higher the score, the better the financial situation.

Doctor Susan DelVecchio, Hawa Meric, Charles Foltz $\&$ Jean-Rene Pelletier conducted a study on the topic of consumers' perceptions of online credit

card theft. The sampling framework includes consumers located in metropolitan areas, whose household income exceeds $\$ 50000$. Specifically, if more than $40 \%$ of households have an income of more than $\$ 50000$ and the average house price is higher than the national average, the postal code of the metropolitan area should be included. Consumers living in these families were randomly selected from the telephone list of a city in the southeast. Each randomly selected consumer receives an email. This email includes a customized cover letter, a copy of the survey report and an addressed postage envelope. The cover letter explains the academic nature of the research and ensures confidentiality. After three weeks, the second wave of requests was sent only to non respondents. Initial requests have been sent to 721 families. Complete and usable responses were received from 181 consumers, with a response rate of $25.1 \%$ (181 / 721). Authors conducted exploratory factor analysis to better understand the structure of data and find the perceived risk dimensions of online shopping. Before exploratory factor analysis, the total project correlation was calculated. Items with low total correlation $(r<0.2)$ were excluded (Mehrabian and Russell 1974) ${ }^{[8]}$. Factor analysis was performed on all remaining items in each scale, and the principal component decomposition was obtained (factors with eigenvalues greater than 1.0 were retained), rotating the principal factor solution according to the varimax program. The item with the highest load is used to explain the basic dimensions of the perceived risk structure and calculate the total score of all identified sub scales. When a project has a high load on multiple factors, the project is assigned to the factor with the highest load (DelVecchio et al., 2002b) ${ }^{[4]}$.

\section{RESULT \& DISCUSSION}

The results of mentioned studies show that there is a direct inverse relationship between credit card ownership time and consumption increase. Users who have credit cards for less than 5 years believe that credit cards will bring more consumption. Users with credit cards for more than 5 years use credit cards more to obtain shortterm financial support and transaction convenience. When users know more about supplementary / competitive credit card systems, they will use credit cards more to facilitate transactions. In addition, when users know more about personal finance, they will use credit cards to provide short-term financial support. Users think that credit card provides them with a way to enter the mainstream society, they will use credit for short-term financial support. In addition, when users have high financial confidence in the use of credit cards, they will use credit cards more to facilitate transactions.

The result of student credit card usage study shows that both the level of credit card debt and the number of credit cards held are declining, and students are more likely to report monthly repayment balances. In addition, with the passage of time, students' attitude towards debt has become more and more negative, their ratings of two items have become more and more negative, and their financial situation has improved. Over time, there was no difference in income, delayed satisfaction, and one of the three students' attitudes towards debt projects ("students should be discouraged from using credit cards"). It is worth noting that some of these changes occurred before the implementation of the credit card law, while others occurred after the implementation of the credit card law.

The result of the study on consumers' perceptions of online credit card theft shows that consumers believe that online shopping is more risky than traditional shopping. However, at present, many indicators to measure consumers' risk perception combine the risk of receiving the required products with the risk of credit card abuse. As online shoppers are looking for a convenient way of retail shopping, any loss, whether in time or in obtaining their own credit line, may be a preventive measure. The loss of convenience or time may allow such shoppers to continue browsing rather than buying online. Retailers in the online world may want to consider security indicators, 
which can be used as preventive measures (to make consumers think it is an extremely unlikely loss) or correction (for example, a user-friendly system that can remind consumers of credit card companies, national credit reporting agencies and government sources (provided at the same time in case of online theft). The scale provided by this study may help to assess the sensitivity of online shoppers to these forms of risk.

\section{CONCLUSION}

Based on the results of current researches, we find that there is a significant relationship between education level and competitive credit card system knowledge. Specifically, users with higher education have a higher understanding of the credit card system, while the understanding of the credit card system is positively correlated with the use of credit card transaction convenience. Respondents with higher education level tend to own use more credit cards. Low and middleincome families are more likely to use credit cards than high-income families, but the study result did not show a correlation between age and credit card consumption habits. Nowadays, more and more credit card holders are willing to use credit card payment through online shopping. As online shoppers are looking for a convenient way of retail shopping, any loss, whether in time or in obtaining their own credit line, may be a preventive measure. The loss of convenience or time may allow such shoppers to continue browsing rather than buying online. All these consumer habits and increasingly complete American credit system put more risk on the theft of credit cards

\section{REFERENCES}

[1] Becker, R. A., Volinsky, C., \& Wilks, A. R. (2010). Fraud Detection in Telecommunications: History and Lessons Learned. Technometrics, 52(1), 20-33.

[2] Boni, B. (2002). Card Fraud - More Serious Than Given Credit For. Network Security, 2002(6), 16-17.

[3] Wickramasinghe, V., \& Gurugamage, A. (2011). Effects of social demographic attributes, knowledge about credit cards and perceived lifestyle outcomes on credit card usage. International Journal of Consumer Studies, 36(1), 80-89.

[4] DelVecchio, S., Meric, H., Foltz, C., \& Pelletier, J. R. (2002b). Exploring Consumers' Perceptions of Online Credit Card Theft. Journal of Internet Commerce, 1(2), 17-36.

[5] Gießmann, S. (2018). Money, Credit, and Digital Payment 1971/2014: From the Credit Card to Apple Pay. Administration \& Society, 50(9), 1259-1279.

[6] Guseva, A., \& Rona-Tas, A. (2001). Uncertainty, Risk, and Trust: Russian and American Credit Card
Markets Compared. American Sociological Review, 66(5), 623.

[7] Lachance, M. J., Beaudoin, P., \& Robitaille, J. (2006). Quebec young adults' use of and knowledge of credit. International Journal of Consumer Studies, 30(4), 347-359.

[8] Mehrabian, Albert and James A. Russell, An Approach to Environmental Psychology (Ann Harbor, MIT Press: 1974), pp. 23-55

[9] Meier, S., \& Sprenger, C. (2010). Present-Biased Preferences and Credit Card Borrowing. American Economic Journal: Applied Economics, 2(1), 193 210.

[10] Mylonakis, J., \& Diacogiannis, G. (2010). Evaluating the Likelihood of Using Linear Discriminant Analysis as A Commercial Bank Card Owners Credit Scoring Model. International Business Research, 3(2).

[11] Nai, W., Liu, L., Wang, S., \& Dong, D. (2018). Modeling the Trend of Credit Card Usage Behavior for Different Age Groups Based on Singular Spectrum Analysis. Algorithms, 11(2), 15.

[12] Norvilitis.J.M.(2014). Changes over Time in College Student Credit Card Attitudes and Debt: Evidence from One Campus. Journal of Consumer Affairs, 48(3), 634-647. [7] Agarwal, S., Skiba, P. M., \& Tobacman, J. B. (2009). Payday Loans and Credit Cards: New Liquidity and Credit Scoring Puzzles? SSRN Electronic Journal. Published.

[13] Sánchez, J. M. (2014). Why Is Credit Card Delinquency Declining? Economic Synopses, 2014(25).

[14] Wickramasinghe, V., \& Gurugamage, A. (2011). Effects of social demographic attributes, knowledge about credit cards and perceived lifestyle outcomes on credit card usage. International Journal of Consumer Studies, 36(1), 80-89. 